\title{
Synthesis of Analogs of Amathamide A and Their Preliminary Antimicrobial Activity
}

\author{
Moisés Ramírez-Osuna ${ }^{1}$, Daniel Chávez ${ }^{1}$, Lourdes Hernández ${ }^{2}$, Elias Molins ${ }^{3}$, Ratnasamy \\ Somanathan ${ }^{1}$ and Gerardo Aguirre ${ }^{1, *}$
}

${ }^{1}$ Centro de Graduados e Investigación, Instituto Tecnológico de Tijuana, Apartado Postal 1166, 22000, Tijuana, B.C., México

${ }^{2}$ Escuela Nacional de Ciencias Biológicas, Instituto Politécnico Nacional, México, D.F, México

${ }^{3}$ Instituto de Ciencia de Materiales de Barcelona (CSIC), Campus de la UAB, 08193 Cerdanyola (Barcelona), Spain
* Author to whom correspondence should be addressed. Tel.: (+52) 664 623-3772; Fax: (+52) 664 623-4043; E-mail: gaguirre@tectijuana.mx

Received: 20 August 2004; in revised form 6 January 2005 / Accepted: 7 January 2005 / Published: 31 January 2005

\begin{abstract}
Syntheses of three non-brominated analogs of amathamide A (1), a natural alkaloid isolated from the Tasmanian marine bryozoan Amathia wilsoni, are described. Antimicrobial activity against Bacillus subtilis, Staphylococcus aureus, Escherichia coli, Pseudomona aeruginosa, and Candida albicans was tested. Test results for amathamide A (1) showed a weak activity against $C$. albicans and E. coli. The three non-natural analogs 2-4 proved to be inactive compounds.
\end{abstract}

Keywords: Organic synthesis, Amathamide A, Antimicrobial activity.

\section{Introduction}

Amathamide A (1) is a brominated alkaloid isolated from the Tasmanian bryozoan Amathia wilsoni Kirkpatrick [1,2]. Biological activity of this type of enamide alkaloids has not been well studied, and only nematocidal, antifungal, and antibacterial activitity has been described for amathamides A (1), B, G, H, and I, isolated from A. wilsoni and A. convolute species [3]. Our previous work relating to the synthesis of two natural amathamides (A and B) [4] prompted us to investigate the 
synthesis and biological evaluation of analogs of this type of alkaloid. Therefore, we selected amathamide A (1) as a lead compound and we carried out the synthesis of three non-brominated analogs 2-4, maintaining the $N$-methyl or substituting it by a single hydrogen or $t$-butylcarbamate (Figure 1). Antimicrobial activity was then determined against two Gram-positive bacteria (B. subtilis and $S$. aureus), two Gram-negative bacteria (E. coli and P. aeruginosa) and a yeast (C. albicans).

\section{Figure 1.}

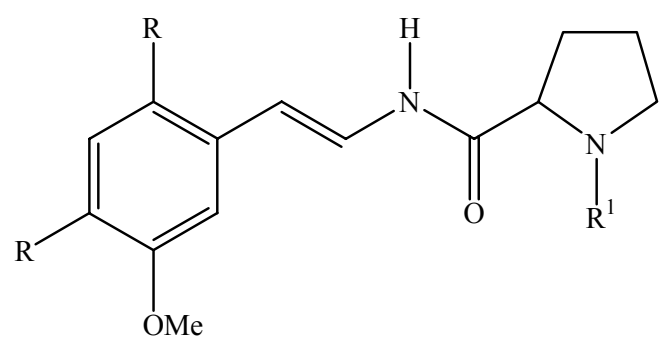

\begin{tabular}{|c|c|c|}
\hline Compound & $\mathbf{R}$ & $\mathbf{R}^{\mathbf{1}}$ \\
\hline $\mathbf{1}$ & $\mathrm{Br}$ & $\mathrm{CH}_{3}$ \\
$\mathbf{2}$ & $\mathrm{H}$ & $\mathrm{CH}_{3}$ \\
$\mathbf{3}$ & $\mathrm{H}$ & $\mathrm{Boc}$ \\
$\mathbf{4}$ & $\mathrm{H}$ & $\mathrm{H}$ \\
\hline
\end{tabular}

\section{Results and Discussion}

Amathamide A (1) was synthesized as previously reported [4]. For the three non-natural analogs, the synthetic route was modified as shown in Scheme 1. m-Anisaldehyde was condensed with nitromethane in $81 \%$ yield in the presence of ammonium acetate and then thiophenol was incorporated via Michael addition with a catalytic amount of $N$-isopropylcyclohexylamine to obtain the product 6 in $90 \%$ yield. Nitro group reduction was achieved in $45 \%$ yield in the conventional manner [5] using $\mathrm{Zn}$ in $\mathrm{AcOH} / \mathrm{HCl}$. Acylation of the amine with $(S)-N$ - $t$-butoxycarbonylproline in presence of DCC/HOBt gave 8 in $20 \%$ yield. Removal of the Boc ( $t$-butoxycarbonyl) protective group from compound $\mathbf{8}$ affords $\mathbf{9}$ in very good yield and acylation of the latter with formaldehyde and reduction with $\mathrm{NaBH}_{3} \mathrm{CN}$ afford 10 (80\% yield). Elimination of thiophenol of $\mathbf{1 0}$ via oxidation with $\mathrm{NaIO}_{4}$ to the sulfoxide and refluxing in toluene $/ \mathrm{K}_{2} \mathrm{CO}_{3}$, gave the non-brominated analogue 2 . On the other hand, elimination of thiophenol from 8 led to analogue 3, and removal of Boc afforded 4 . In this manner, we obtained the three non-natural analogs of amathamide A (1).

The preliminary antimicrobial activity of amathamide A (1) and the three non-natural analogs 2-4 was determined against the Gram-positive bacteria $S$. aureus and B. subtuilis, the Gram-negative bacteria $E$. coli and $P$. aeruginosa and the yeast $C$. albicans by using the agar dilution-streak assay (Mitscher method) [6]. Only compound 1 was active in the bioassay at the final concentration of 200 $\mu \mathrm{g} / \mathrm{mL}$. Minimal inhibitory concentrations (MIC) for $\mathbf{1}$ were determined [7,8]. The MICs of 1 for $C$. albicans and E. coli were weak, and less active (MICs greater than $128 \mu \mathrm{g} / \mathrm{mL}$ ) for P. aeruginosa, $S$. aureus, and B. subtilis (Table 1).

\section{Scheme 1.}


<smiles>COc1cccc(/C=C/N(CC(C)C)C(=O)C2CCCN2C)c1</smiles>

(a) $\mathrm{CH}_{3} \mathrm{NO}_{2}, \mathrm{AcOH}, \mathrm{AcONH}_{4}$; (b) $\mathrm{PhSH}$; (c) $\mathrm{Zn}, \mathrm{HCl}, \mathrm{AcOH}$; (d) $\mathrm{DCC} / \mathrm{HOBt}$, DMAP, $(S)$ - $N$-t -butoxycarbonylproline; (e) $\mathrm{NaIO}_{4}, \mathrm{MeOH}$; Toluene, $\mathrm{K}_{2} \mathrm{CO}_{3}$, reflux. (f) $\mathrm{HF}$, reflux (g) $\mathrm{H}_{2} \mathrm{CO}, \mathrm{NaBH}_{3} \mathrm{CN}$.

Table 1. Minimal Inhibitory Concentration (MIC) of 1, Nystatin and Streptomycin toward Pathogenic Bacteria and yeast.

\begin{tabular}{lccc}
\hline Pathogen & $\mathbf{1}^{\mathrm{a}}$ & Nystatin $^{\mathrm{a}}$ & Streptomycin $^{\mathrm{a}}$ \\
\hline C. albicans & 142.8 & 10.0 & - \\
E. coli & 71.4 & - & 10.0 \\
P. aeruginosa & 71.4 & - & 0.5 \\
S. aureus & 142.8 & - & 1.6 \\
B. subtilis & 142.8 & - & 3.1 \\
\hline
\end{tabular}

${ }^{\mathrm{a}}$ Results are means of two determinations and are expressed as $\mu \mathrm{g} / \mathrm{mL}$ 


\section{Conclusions}

The non-brominated analogues of amathamides obtained following a simpler synthetic route proved to be inactive compounds. Thus, we conclude that the presence of bromine on the aryl ring contributes to the antimicrobial activity of amathamide A (1). According to Narkowicz et al. [3], the $E$ orientation of the double bond of amathamide A (1) conferred the highest biological activity compared with the less constrained saturated version, as in amathamide I, or the $Z$ orientation of the double bond as in amathamide B. This information leaves only the possibility of altering the acyl group and/or substitution on the amide nitrogen in an effort to obtain analogues with enhanced antimicrobial activity for further biological testing. The effect of other aryl substituents could also be explored.

\section{Acknowledgments}

We gratefully acknowledge support for this project by CONACYT grant E130,1517 (2001).

\section{Experimental}

\section{General}

Melting points were determined on a Fisher-Johns melting point apparatus and are uncorrected. (IR) spectra were taken on a Perkin Elmer FT-IR 1600 spectrometer. ${ }^{1} \mathrm{H}-(200 \mathrm{MHz})$ and ${ }^{13} \mathrm{C}-\mathrm{NMR}(75$ $\mathrm{MHz}$ ) spectra were recorded on a Bruker Avance DPX-300 MHz spectrometer. Spectra were run in $\mathrm{CDCl}_{3}$ with tetramethylsilane (TMS) used as internal standard. The EIMS data was obtained on a Finnigan MAT-90 instrument and all experiments were performed in the electron-impact mode (EI) at $70 \mathrm{eV}$ using a direct insertion probe.

(E)-3-Methoxy- $\beta$-nitrostyrene (5): To a solution of $m$-anisaldehyde $(73.4 \mathrm{mmol}, 10.0 \mathrm{~g})$ in glacial $\mathrm{AcOH}(120 \mathrm{~mL})$ was added $\mathrm{AcONH}_{4}(2.71 \mathrm{~g})$ and nitromethane $(13.1 \mathrm{~mL})$. The solution was heated under reflux for $1 \mathrm{~h}$. The mixture was cooled and the precipitate was washed with water and recrystalized from $\mathrm{AcOH} / \mathrm{H}_{2} \mathrm{O}$ to give a yellowish solid (10.6 g, 81\%); mp 88-89 $\mathrm{C}$; IR (KBr): 3108 , 1636, 1577, $1511 \mathrm{~cm}^{-1}$; ${ }^{1} \mathrm{H}-\mathrm{NMR}: \delta 7.97(\mathrm{~d}, J=14.0 \mathrm{~Hz}), 7.56(\mathrm{~d}, J=14.0 \mathrm{~Hz}), 7.41-7.02(\mathrm{~m}, 4 \mathrm{H})$, $3.85\left(\mathrm{~s}, 3 \mathrm{H}, \mathrm{OC}_{3}\right)$.

2-(3-Methoxyphenyl)-2-(thiophenyl)-1-nitroethane (6): Compound 5 (22.3 mmol, $4.0 \mathrm{~g})$ was dissolved in $\mathrm{CH}_{2} \mathrm{Cl}_{2}(100 \mathrm{~mL})$ and was added thiophenol $(22.9 \mathrm{mmol}, 2.6 \mathrm{~mL})$ and $0.5 \mathrm{~mL}$ of $N$-isopropylcyclohexylamine. The resulting solution was stirred for $1 \mathrm{~h}$. at $\mathrm{rt}$. The solution was concentrated and subjected to flash chromatography using hexane $/ \mathrm{CH}_{2} \mathrm{Cl}_{2}(80: 20)$. Removal of the solvent gave a brownish oil (5.8 g, 90\%). IR (film): 3057, 2957, 1599, 1554, $1262 \mathrm{~cm}^{-1} ;{ }^{1} \mathrm{H}-\mathrm{NMR}: \delta$ 7.45-7.22 (m, $6 \mathrm{H}), 6.85-6.79(\mathrm{~m}, 3 \mathrm{H}), 4.83-4.60(\mathrm{~m}, 3 \mathrm{H}), 3.75\left(\mathrm{~s}, 3 \mathrm{H}, \mathrm{OC}_{3}\right)$.

2-(3-Methoxyphenyl)-2-(thiophenyl)-1-aminoethane (7): Compound 6 (17.3 mmol, 5.0 g) was dissolved in $\mathrm{AcOH}(46 \mathrm{~mL})$ and $\mathrm{Zn}$ powder (172.4 mmol, $11.3 \mathrm{~g})$ was added. Then conc. $\mathrm{HCl}(37 \mathrm{~mL})$ 
was added dropwise and the solution was stirred overnight at $\mathrm{rt}$. The solution was neutralized with $2 \mathrm{~N}$ $\mathrm{NH}_{4} \mathrm{OH}$. The residue was extracted into ethyl acetate $(2 \times 100 \mathrm{~mL})$ and the solvent was removed under reduced pressure to give a yellowish green oil (2.0 g, 45\%); IR (film): 3372, 3057, 2936, 1587, 1483, 1261, 1044, $694 \mathrm{~cm}^{-1}$; ${ }^{1} \mathrm{H}-\mathrm{NMR}: \delta$ 7.4-7.18 (m, 6H), 6.96-6.70 (m, 3H), 4.12 (t, $\left.J=8 \mathrm{~Hz}\right), 3.77$ (s, 3H, $\left.\mathrm{OC}_{3}\right), 3.20-3.00(\mathrm{~m}, 2 \mathrm{H}), 2.00-1.40\left(\mathrm{bs}, 2 \mathrm{H}, \underline{\mathrm{N}}_{2}\right)$.

2(S)-N-[2(3-Methoxyphenyl)-2-(thiophenyl)ethanyl]-1-t-butoxycarbonylproline (8): To a solution of (S)- $N$-t-butoxycarbonylproline $(19.5 \mathrm{mmol}, 4.1 \mathrm{~g})$ in dry THF $(100 \mathrm{~mL})$ was added dicyclohexylcarbodiimide (19.5 mmol, $4.0 \mathrm{~g}$ ), 1-hydroxybenzotriazole (19.5 mmol, $2.6 \mathrm{~g})$ and 4-N,N-dimethylaminopyridine in catalytic amounts. A solution of 7 (19.5 mmol, $5.05 \mathrm{~g})$ in dry THF $(20 \mathrm{~mL})$ was added and the suspension was stirred for $24 \mathrm{~h}$, filtered and the solvent was removed in vacuo. The residue was purified by flash chromatography using $\mathrm{CH}_{2} \mathrm{Cl}_{2} / \mathrm{MeOH}$ (95:5). Removal of the solvent gave a brownish oil (1.8 g, 20\%); IR (film): 3313, 3056, 2974, $1697 \mathrm{~cm}^{-1}$; ${ }^{1} \mathrm{H}-\mathrm{NMR}$ : $\delta$ 7.50-7.20 (m, $6 \mathrm{H}), 6.90-6.76(\mathrm{~m}, 3 \mathrm{H}), 4.50-4.30(\mathrm{~m}, 1 \mathrm{H}), 4.30-4.10(\mathrm{~m}, 1 \mathrm{H}), 3.75\left(\mathrm{~s}, 3 \mathrm{H}, \mathrm{OC}_{3}\right), 3.90-3.50(\mathrm{~m}, 2 \mathrm{H})$, 3.50-3.20 (m, 2H), 2.40-1.60 (m, 4H), 1.39 (s, 9H, boc); ${ }^{13} \mathrm{C}-\mathrm{NMR}: \delta$ 159.6, 140.7, 133.7, 132.2, $129.5,128.8,127.3,127.2,120.0,113.3,113.2,113.1,80.3,55.1,52.3,46.9,43.8,43.6,28.3$ : IEMS, $m / z: \mathrm{M}^{+} 456$ (nd), [M-PhSH] 346 (23), 198 (3), 149 (62), 132 (2), 70 (100), 57 (33).

2(S)-N-[2(3-Methoxyphenyl)-2-(thiophenyl)ethanyl]-2-pyrrolinecarboxamide (9): Compound 8 (4.38 mmol, $2.0 \mathrm{~g})$ was dissolved in acetonitrile $(30 \mathrm{~mL})$ and $\mathrm{HF}(50 \%, 0.7 \mathrm{~mL})$ was added and the mixture heated overnight under reflux with magnetic stirring. The mixture was cooled and the solvent was removed in vacuo. The residue was treated with $\mathrm{K}_{2} \mathrm{CO}_{3}(50 \%, 20 \mathrm{~mL})$ and extracted with dichloromethane $(2 \times 20 \mathrm{~mL})$. The organic layer was dried over anhydrous sodium sulfate and concentrated to give 9 (1.51 g, 97\%). Compound 9 was used in the next step without further purification. IR (film): 3322, 3054, 2960, $1665 \mathrm{~cm}^{-1}$.

2(S)-N-[2(3-Methoxyphenyl)-2-(thiophenyl)ethanyl]-1-methyl-2-pyrrolinecarboxamide (10): 9 (4.24 mmol, $1.5 \mathrm{~g})$ was dissolved in acetonitrile $(14 \mathrm{~mL})$ and formaldehyde $(37 \%, 2.3 \mathrm{~mL})$ and sodium cyanoborohydride ( $9.19 \mathrm{mmol}, 0.6 \mathrm{~g}$ ) were added and the solution was stirred for $2 \mathrm{~h}$. at $\mathrm{rt}$. The solution was neutralized with $\mathrm{AcOH}$ and stirring was continued for $2 \mathrm{~h}$. The solvent was removed under vacuum and the residue was washed with water and extracted with $\mathrm{CH}_{2} \mathrm{Cl}_{2}(2 \times 15 \mathrm{~mL})$. The organic layer was dried over anhydrous sodium sulfate and concentrated to give a brownish oil of the title compound as a mixture of diastereomers (1.2 g, 80\%). IR (film): 3328, 3056, 2942, 1663, 1261 $\mathrm{cm}^{-1}$; ${ }^{1} \mathrm{H}-\mathrm{NMR}: \delta 7.56$ (bs, 2H, N-H), 7.38-7.160 (m, 12H), 6.88-6.75 (m, 6H), 4.42-4.32 (m, 2H), 3.87-3.55 (m, $4 \mathrm{H}), 3.76\left(\mathrm{~s}, 6 \mathrm{H}, \mathrm{OCH}_{3}\right), 3.00-2.93(\mathrm{~m}, 2 \mathrm{H}), 2.80(\mathrm{dd}, J=10.0,4.0 \mathrm{~Hz}, 2 \mathrm{H}), 2.32-2.00$ $(\mathrm{m}, 4 \mathrm{H}), 2.22\left(\mathrm{~s}, 3 \mathrm{H}, \mathrm{NCH}_{3}\right), 2.15\left(\mathrm{~s}, 3 \mathrm{H}, \mathrm{NC}_{3}\right), 1.50-1.80(\mathrm{~m}, 6 \mathrm{H}) ;{ }^{13} \mathrm{C}-\mathrm{NMR}: \delta 174.9,174.8,159.8$, 141.0, 141.0, 134.1, 132.1, 132.1, 129.9, 129.6, 129.1, 128.9, 127.5, 127.4, 127.3, 120.4, 120.3, 113.4, $113.4,113.4,113.3,68.8,56.6,56.5,55.2,52.2,43.6,43.5,41.6,41.5,31.0,30.9,24.22$.

2(S)-N-[(E)-2(3-Methoxyphenyl)ethanyl]-1-methyl-2-pyrrolinecarboxamide (2): To a solution of 10 $(1.7 \mathrm{mmol}, 0.6 \mathrm{~g})$ in methanol $(10 \mathrm{~mL})$ was added a solution of sodium periodate $(1.9 \mathrm{mmol}, 0.4 \mathrm{~g})$ in water $(10 \mathrm{~mL})$ and the resulting mixture heated under reflux for $1.5 \mathrm{~h}$. The methanol was removed in 
vacuo and the aqueous residue was extracted with dichloromethane $(2 \times 20 \mathrm{~mL})$. The organic layer was dried over anhydrous sodium sulfate and concentrated to give sulfoxide as a brownish oil $(0.57 \mathrm{~g}$, $70 \%)$. The crude product was then used in the next step without purification. The sulfoxide (1.20 mmol, $0.465 \mathrm{~g})$ was dissolved in toluene $(30 \mathrm{~mL})$, sodium carbonate was added $(166 \mathrm{mg})$ and the mixture heated under reflux for $2 \mathrm{~h}$. The solvent was removed under vacuum and the residue was purified by circular chromatography using $\mathrm{CH}_{2} \mathrm{Cl}_{2} / \mathrm{MeOH}$ (95:5). Removal of the solvent gave a brownish oil (0.16 g, 35\%). IR (film): 3286, 2942, 1681, 1650, 1504, $1262 \mathrm{~cm}^{-1} ;{ }^{1} \mathrm{H}-\mathrm{NMR}$ : $\delta 9.21$ (d, $J$ $=10.8 \mathrm{~Hz}, 1 \mathrm{H}, \mathrm{N}-\mathrm{H}), 7.40(\mathrm{dd}, J=14.0,12.0 \mathrm{~Hz}, 1 \mathrm{H}), 7.20(\mathrm{t}, J=8.0 \mathrm{~Hz}, 1 \mathrm{H}), 6.94-6.85(\mathrm{~m}, 2 \mathrm{H})$, $6.73(\mathrm{ddd}, J=8.2,2.6,0.8 \mathrm{~Hz}, 1 \mathrm{H}), 6.17(\mathrm{~d}, J=14.0 \mathrm{~Hz}, 1 \mathrm{H}), 3.81\left(\mathrm{~s}, 3 \mathrm{H}, \mathrm{OCH}_{3}\right), 3.24-3.17(\mathrm{~m}, 1 \mathrm{H})$, $3.07(\mathrm{dd}, J=9.8,4.8 \mathrm{~Hz}, 1 \mathrm{H}), 2.42\left(\mathrm{~s}, 3 \mathrm{H}, \mathrm{NC}_{3}\right), 2.50-2.20(\mathrm{~m}, 2 \mathrm{H}), 2.00-1.70$ (m, 3H); ${ }^{13} \mathrm{C}-\mathrm{NMR}: \delta$ $172.2,159.9,137.7,129.6,122.5,118.4,113.3,112.5,110.6,68.7,56.7,55.2,41.9,31.0,24.5$; IEMS, $m / z: \mathrm{M}^{+} 260(26), 132(15), 112(18), 70$ (100).

2(S)-N-[(E)-2(3-Methoxyphenyl)ethanyl]-1-t-butoxycarbonyl-2-pyrrolinecarboxamide (3): Compound 3 was synthesized from $8(2.2 \mathrm{mmol}, 1.0 \mathrm{~g})$ using the same procedure described for amide 2. Compound 3 was obtained as a white solid (0.30 g, 30\%); IR (KBr): 3283, 2974, 1695, 1653, 1400, 1257, 1161, $774 \mathrm{~cm}^{-1}$; ${ }^{1} \mathrm{H}-\mathrm{NMR}: \delta 9.28(\mathrm{bs}, 1 \mathrm{H}, \mathrm{N}-\mathrm{H}), 7.46$ (dd, $\left.J=14.6,10.8 \mathrm{~Hz}, 1 \mathrm{H}\right), 7.19(\mathrm{t}, J=7.8$ $\mathrm{Hz}, 1 \mathrm{H}), 6.90(\mathrm{~d}, J=7.8,1 \mathrm{H}), 6.85(\mathrm{~d}, J=2.4,1 \mathrm{H}), 6.73(\mathrm{dd}, J=8.2,2.4 \mathrm{~Hz}, 1 \mathrm{H}), 6.08(\mathrm{~d}, J=14.6$ $\mathrm{Hz}, 1 \mathrm{H}), 4.42-4.22(\mathrm{~m}, 1 \mathrm{H}), 3.77\left(\mathrm{~s}, 3 \mathrm{H}, \mathrm{OCH}_{3}\right), 3.56-3.2(\mathrm{~m}, 2 \mathrm{H}), 2.60-1.80(\mathrm{~m}, 4 \mathrm{H}), 1.49(\mathrm{~s}, 9 \mathrm{H})$; IEMS, $m / z \mathrm{M}^{+} 346$ (23), 245 (1), 198 (2), 149 (42), 132 (6), 70 (100), 57 (33).

2(S)-N-[(E)-2(3-Methoxyphenyl)ethanyl]-2-pyrrolinecarboxamide (4): Compound 4 was obtained from $3(0.6 \mathrm{mmol}, 0.2 \mathrm{~g})$ as a brownish oil $(0.13 \mathrm{~g}, 90 \%)$ using the same procedure described for amide 9. IR (film) 3272, 3062, 2956, 1679, 1649, 1528, 1260, 1043, $692 \mathrm{~cm}^{-1} ;{ }^{1} \mathrm{H}-\mathrm{NMR}: \delta 9.58$ (d, $J=$ $10.6 \mathrm{~Hz}, 1 \mathrm{H}, \mathrm{N}-\mathrm{H}), 7.44(\mathrm{dd}, J=15.0,11.3 \mathrm{~Hz}, 1 \mathrm{H}), 7.19$ (t, $J=8.0 \mathrm{~Hz}, 1 \mathrm{H}), 6.91(\mathrm{~d}, J=7.8,1 \mathrm{H})$, $6.87(\mathrm{~d}, J=2.0 \mathrm{~Hz}, 1 \mathrm{H}), 6.72(\mathrm{ddd}, J=8.0,2.4,0.8 \mathrm{~Hz}, 1 \mathrm{H}), 6.16(\mathrm{~d}, J=15 \mathrm{~Hz}, 1 \mathrm{H}), 3.91-3.75(\mathrm{~m}$, $1 \mathrm{H}), 3.80\left(\mathrm{~s}, 3 \mathrm{H}, \mathrm{OC}_{3}\right), 3.10-2.90(\mathrm{~m}, 2 \mathrm{H}), 2.65-2.3(\mathrm{bs}, 1 \mathrm{H}, \mathrm{N} \underline{\mathrm{H}}), 2.26-2.15(\mathrm{~m}, 1 \mathrm{H}), 2.06-1.90(\mathrm{~m}$, 1H), 1.81-1.71 (m, 2H); ${ }^{13} \mathrm{C}-\mathrm{NMR}: \delta$ 172.9, 160.0, 138.0, 129.8, 122.6, 118.5, 113.5, 112.6, 110.7, 60.5, 55.4, 47.5, 30.9, 26.4; IEMS $m / z \mathrm{M}^{+} 246$ (25), 149 (16), 132 (3), 70 (100).

\section{Bioassay Evaluation Procedures.}

Antimicrobial activity against Gram-positive bacteria Staphylococcus aureus ATCC 6538 and Bacillus subtilis ATCC 6633, Gram-negative bacteria Escherichia coli ATCC 8739 and Pseudomona aeruginosa ATCC 9027, and yeast Candida albicans ATCC 10231 was determined by the agar Mitscher method as previously described [5]. Test samples were dissolved $(2 \mathrm{mg} / \mathrm{mL})$ in $10 \mathrm{~mL}$ nutrient agar medium No. 1 (Merck) for bacterial cultures and Sabouraud agar (Merck) supplemented with glucose (4\%) for yeast, and added aseptically to each Petri dish and swirled carefully until the agar began to set. After $24 \mathrm{~h}$. of incubation (sterility test) the bacteria or yeast in a concentration of approximately $0.5 \mathrm{McFarland}$ were streaked in radial patterns on the agar plates containing the samples, incubated at $37^{\circ} \mathrm{C}$ for $24 \mathrm{~h}$, except for C. albicans which was incubated at $25^{\circ} \mathrm{C}$. Complete inhibition of bacterial growth was expected for a sample to be declared active. Inhibition was present 
at $200 \mu \mathrm{g} / \mathrm{mL}$ only for amathamide A (1). Minimal inhibitory concentrations (MICs) values were determined by the dilution method previously described [6,7]. Two-fold serial dilutions were tested in nutrient broth (Merck) for B. subtilis, S. aureus, E. coli and P. aeruginosa, and Sabouraud-glucose (2 \%) nutrient broth (Merck) for C. albicans. An initial concentration of $1 \mathrm{mg} / \mathrm{mL}$ of sample was prepared by dissolving in dimethyl sulphoxide. Serial dilutions $(100-0.1 \mu \mathrm{g} / \mathrm{mL})$ of sample were prepared, and the liquid medium was inoculated by cultures in stationary phase at concentration of $10^{5}$ $\mathrm{CFU} / \mathrm{mL}$. After overnight incubation, the MIC was determined as the lowest concentration of compound preventing any visible growth. Streptomycin sulfate (Sigma) $(1 \mu \mathrm{g} / \mathrm{mL})$ and nystatin (Sigma) $(3 \mu \mathrm{g} / \mathrm{mL})$ were used as positive controls.

\section{References}

1. Blackman, A. J.; Matthews, D. J. Heterocycles 1985, 23, 2829-2832.

2. Blackman, A. J.; Green, R. D. Aust. J. Chem., 1987, 40, 1655-1662.

3. Narkowicz, C.; Blackman, A. J.; Lacey, E.; Gill, J.; Heiland, K. Proceedings of ICNP-2002Trabzon / Türkiye, 2002, 26-29.

4. Ramirez-Osuna, M.; Aguirre, G.; Somanathan, R.; Molins, E. Tetrahedron-Asymmetry 2002, 13, 2261-2266.

5. Ioeffe, S. L.; Tartakovskii, V. A.; Novikov, S. S. Russ. Chem. Rev. 1966, 35, 19-32.

6. Mitscher. L. A.; Leu. R. P.; Bathala. M. S.; Wu. W. N.; Beal. J.L. Lloydia 1972, 35, 157-166.

7. Vanden Berghie, D. A.; Vlietinck, A. J. In: Methods in Plant Biochemistry; Hostettman, K., Ed.; Academic Press: London, 1991; Chapter 3, pp. 47-69.

8. Sahm, D. F.; Washington II, J. A. In: Manual of Clinical Microbiology; Balows, A., Ed.; American Society for Microbiology: Washington, DC, 1991; 5th ed. Chapter 6, pp. 1105-1116.

Sample availability: Contact authors

(C) 2005 by MDPI (http://www.mdpi.org). Reproduction is permitted for noncommercial purposes. 